John Carroll University

Carroll Collected

2017

\title{
Poetic Science: Wonder and the Seas of Cognition in Bacon and Pericles
}

Jean Feerick

John Carroll University, jfeerick@jcu.edu

Follow this and additional works at: https://collected.jcu.edu/fac_bib_2017

Part of the English Language and Literature Commons

\section{Recommended Citation}

Feerick, Jean, "Poetic Science: Wonder and the Seas of Cognition in Bacon and Pericles" (2017). 2017 Faculty Bibliography. 36. https://collected.jcu.edu/fac_bib_2017/36

This Book Chapter is brought to you for free and open access by the Faculty Bibliographies Community Homepage at Carroll Collected. It has been accepted for inclusion in 2017 Faculty Bibliography by an authorized administrator of Carroll Collected. For more information, please contact connell@jcu.edu. 


\title{
Poetic Science: Wonder and the Seas of Cognition in Bacon and Pericles
}

\author{
Jean E. Feerick
}

\section{The Art of Knowing in Early Modern Culture}

The two-culture society that C.P. Snow famously warned against in a lecture he delivered at Cambridge in the 1950s has come to be seen by many as the 'brainchild' of the Renaissance. ${ }^{1}$ According to this historical narrative, the seventeenth century witnessed the rise of empiricism, driven largely by Francis Bacon's vision for reforming natural philosophy. Hailed as the father of modern science, Bacon is credited with liberating science from the towering shadow of Aristotle and the syllogistic method that became entrenched under the Scholastics. But his drive to access the material world untainted by the 'idols' of the mind has also been seen to voice a suspicion toward language and to inaugurate the rupture between science and the arts that would grow into the deep disciplinary divisions that we know today. Hence, the success of Bacon's inductive method has absorbed much of the blame for our two-culture society, which construes the arts and sciences as worlds apart, viewing science as the exclusive domain of knowledge about the material world.

Admittedly, Bacon's account of poetry in his various published volumes does lend credence to this view. In his Advancement of Learning (1605), he identified poetry as 'fained history,' emphasizing the non-mimetic tendencies of this branch of learning. By placing imagination at the center of the creative act, the poet was 'not tyed to the Lawes of Matter,' as was the historian in Bacon's view, but could 'at pleasure ioyne that which Nature hath seuered: \& seuer that which Nature hath ioyned. ${ }^{2}$ As such, he understood the poet as invested in straying from nature's laws, enjoying a freedom to imagine worlds released from material constraints. Bacon contrasted this 'extreamely licensed' quality of poetry, which served in his view to 'raise and erect the Minde,' with

J.E. Feerick (困)

John Carroll University, University Heights, OH, USA 
the activities of reason which 'doth buckle and bowe the Mind unto the Nature of things' (Adv.,73-74). Apparently, where the poet takes flight for unknown of things' ( $A d v$., $73-74$ ). Apparently, where the poet takes filos realms on the wing tethered to the earth. ${ }^{3}$

If here Bacon seems to disapprove of the activities of poetry as a tool of empirical knowledge, he was also attentive to its merits, identifying it as one of the chief branches of learning and as superior to the more empirically faithful discipline of history. ${ }^{4}$ In the revised version of his Advancement of Learning, published in Latin as De Augmentis Scientiarum, he applauds poetry as an essential fabric of man's moral and cognitive life: 'Poetry seems to bestow upon human nature those things which history denies to it; and to satisfy the mind with the shadows of things when the substance cannot be obtained. 5 He praises its ability to respond to the rational soul by correcting (fallen) history, refreshing minds wearied by the 'satiety of ordinary events' (De Aug. $8: 441$ ), and forging a path to morality and magnanimity. As Sachiko Kusukawa observes, Bacon positions poetry as 'superior to history because the former compensates for and supplies the moral values that history fails to teach. ${ }^{16}$

But it is his discussion of dramatic poesy that I would like to probe for evidence of a more capacious way of organizing knowledge-activities in the early modern period, one that defies the walls circumscribing our two-culture mindset and identifies a weakness in attempts to hail the Renaissance as the source of our disciplinary malaise. Noting that the theater could be of 'excellent use if well directed,' Bacon observes its potential both for corruption and discipline, with the former dominating the stage of his moment. A 'toy' in contemporary practice, he yet praises theater's value for antiquity, when 'it was used as a means of educating men's minds to virtue' (De Aug., 8:441). Indeed, he tellingly observes, 'it has been regarded by learned men and great philosophers as a kind of musician's bow by which men's minds may be played upon' (De Aug $8: 441$ ). Here, the theater and its audience are understood as coming together the auditors' minds serving as the instrumental 'matter' to be harmoniously arranged by the skilled 'hands' of the drama. The dramatic performance stands in for an Orpheus or Arion, producing harmonies that subdue disorder and savagery. For Bacon, theater's power builds on one of the 'great secrets of nature,' the fact that 'the minds of men are more open to impressions and affections when many are gathered together than when they are alone' (De Aug., 8:441-2). Responding to this fact of nature, theater emerges for Bacon as a kind of communal cognitive laboratory, a place where the 'matter' of minds are harmoniously rearranged.

Indeed, as I will argue, the poet-dramatist and Bacon's natural philosopher were intimately connected in the early modern period both in how they understood the cognitive process and the techniques they recommended for scaffolding the mind. On this front, natural philosophy and poetry were close cousins, hardly the polarized disciplines that modern culture understands them to be. Seeking to illuminate some of the overlapping contours of science and arts in this moment before the rise of modern disciplines, this chapter will read
Bacon's view of cognition and the role he affords art in managing the mind's activities alongside an explication of the cognitive experience represented by the play Pericles. A collaborative production of both Shakespeare and the dramatist George Wilkins, this play was brought to the stage just a year or two after the publication of Bacon's Advancement of Learning. Although there is a remarkable confluence of dating between these texts, I argue not for direct influence among these writers but for their expression of a distinctive early modern episteme that perceived overlap and synergy between natural philosophy and the arts. In effect, I revisit the purported origins of our two-culture society to dislodge that story, but also to retrieve some countercultural visions of how knowledge might be organized in and around art - that is, to recall the poetic side of science and the 'knowing' side of art.'

Experimental in form in its highly self-conscious appropriation of a traditional dramatic form, signaled by its placement of the medieval poet Gower as narrator of stage events, Pericles bears uncanny resemblances to Bacon's new philosophy at the level of trope and figure. In step with Bacon's philosophical writings, the play offers a view of the mind as an extension of the natural world, participating in its elemental liveliness. Understanding the mind as a sea-like vessel that betrays a tendency toward flux and drift, both the play and Baconian philosophy associate art with the power to call the mind to itself, to momentarily halt its eddying movement. The cessation of mental flow that art enables emerges in both sets of texts as the moment in which knowledge is captured.

Indeed, both Bacon's reformed natural philosophy and Pericles identify a particular species of art-one that creates fabricated or artificial wonders modeled on nature's marvels - as having the unique ability to organize the cognitive faculty. In the elaborate trope of the ship at sea that these authors dwell on, the mind is imagined as a sea upon whose waters the ship of reason attempts to sail, aided in its path by the rudder that is art, a humanly crafted kind of work that can take a variety of forms.$^{8}$ Bacon calls upon his natural philosopher to pursue nature's wonders to their causes, with the aim of eventually reproducing such wonders artificially. ${ }^{9}$ In his view this attentiveness to wondersnatural, artificial, marvelous, or ordinary-will serve as a stepping stone to knowledge, much in the way that Aristotle had valued wonder in his Poetics as a cognitive tool..$^{10}$ Art that replicates nature's wonders aids the mind by breaking the 'works of nature' into constituent parts and impressing the mind with a revelatory jolt. ${ }^{11}$ Bacon's aphorisms, which he saw as containing the "pith and heart of sciences' shorn of dilation, perform a rhetorical version of this technique by rupturing knowledge into pithy verbal maxims so as to enlighten the audience with a "sudden flash of illumination." Such art 'arrests and holds men's contemplation', allowing the practitioner to fully perceive and apprehend 'rare' and 'familiar' things alike, while avoiding the comfort of a big picture, which lulls the mind into a falsely secure posture, much like a 'spell'. Art emerges for Bacon as a cognitive tool that prevents the circular, self-defeating ways of thinking that impede the advance of knowledge for both the individual and society at large. ${ }^{13}$ 
For Shakespeare and Wilkins, the act of blending human labor with nature, which they identify as the role of art, also provides a kind of cognitive support. which the effect of overwhelming man, passively prostrating him, as they do Pericles when he stoically endures loss and hardship, artificial wonders - understood as human imitations of nature's marvels-have the power to enliven and enlighten man, sustaining him in the turbulent jourthe sea she will learn to navigate, is the figure who most embodies this hybridizing of human artifacts with nature's patterning. It is she who leads Pericles to embrace a view of himself as a co-creator with nature, rather than nature's passive instrument. But the play identifies a range of other roles and characters-a doctor, fisherman, and musician--who also embody such a composite, indicating the range of livelihoods this play construes under the broad category of 'artisan.' ${ }^{4}$ For the play, as for Bacon, art is a method that prepares the mind for knowledge as well as an activity that produces knowledge. It guards against a way of knowing the world in which men "touch nature only with the tips of their fingers." 15 As Peltonen has argued in his study of Bacon, "in order to achieve a truly operational science, the ancient gap between the products of nature and those of human art had to be bridged." ${ }^{16}$ At this early modern moment, practicing sound science also meant producing marvelous works of art. ${ }^{17}$

\section{Bacon And the Liquid Tides of Thought}

The frontispiece to Bacon's The New Organon, which famously portrays a ship sailing through the Pillars of Hercules to chart a previously undiscovered world asserts a fundamental truism of the new natural philosophy propounded by Bacon: namely, that his philosophy will enable journeys of discovery, and that the intellectual instrument packaged as the 'new organon' will serve as ship, compass, and navigational tool to advance those pursuits. This tool, he proposes, will expand the intellectual globe in the same way that Columbus, Magellan, and Vespucci had opened up the terrestrial globe. For Bacon, the two projects-intellectual and navigational-are intimately related. The spatial rupture enacted by the explorer's traversal of sea together with the intellectual rupture anticipated by Bacon's new science will combine, in his view, to effect a crucial break from the past.

But the great expanse of sea that beckons explorers and scientists alike in this famous engraving functions not only as an emblem of brave new worlds of nature to be discovered, mastered, and brought to life but also as a model for the organ of understanding itself - the human mind. In the image of sea ship, and protruding pillars that this emblem provides, we get an allegory of an internal landscape, an intellectual globe, as it emerges both in the The New Organon and across Bacon's corpus of writings. It is an image that adopts motifs derived from romance narratives-of journeys and the dangers that riddle them - as well as the explorer's paradigm to describe the operations of cognition. And it is a view of the mind that provides a rather sobering tale of man's intellectual powers-arguably one that expresses a kind of negative exceptionalist view of humanity-in regarding man not as the measure of the world but as an extension of its elemental properties. ${ }^{18}$ In Bacon's hands, the mind ceases to be the stable 'organon' that Aristotle had imagined it as and becomes instead a manifestation of the 'flexuous course' of nature that defines all organic bodies. In using the term 'flexuous' to describe nature, Bacon evoked the 'bends,' 'curves,' 'sinuous,' and 'undulating' motion characteristic of 'waves,' the state of being in constant, unceasing flux. ${ }^{19}$ Similarly, it is such patterns and tendencies that for Bacon define the mind's operations, which emerges as a kind of romance seascape in his writings. His corpus captures a pre-Cartesian account of cognition, wherein the mind was not the exception and opposition to enmattered being that it will eventually become but rather an extreme instance of elemental nature. ${ }^{20}$ His vision for a reformed science thereby calls upon the natural philosopher to disclose the hidden truths of the external world - 'the physical globe, of land, sea and stars' - while also operating on his own internal world-'the intellectual globe' of the mind (NO, 69).

Bacon's tendency to construe the human as embedded within nature, rather than standing apart from it, is evident in his tendency to urge that human faculties, alongside natural phenomena, be taken up as objects of study for the new science. Notably, he includes not only man's physical body but his mental and emotional faculties as objects of scrutiny. In his The New Organon, he makes this plan explicit, declaring 'we are making a history and tables of discovery about anger, fear, shame and so on; and also about instance of political affairs; and equally about the mental motions of memory, composition and division, of judgement, and the rest, no less than of heat and cold, or light, or vegetative growth' (NO., 98). Elemental, botanical, emotional, and social expressions of life emerge here in a tangled cluster that is Bacon's view of nature, each embodying in its own ways aspects of nature's material laws that his new philosophy seeks to codify. As he observes at the start of the second book of the The New Organon: 'It is surely right and useful to spend effort on the anatomy of organic bodies (as of man and of the animals)' (NO., 107). If his language here, as well as in the heading of the section of the text outlining consideration of 'Nature' and the 'Kingdom of Man,' suggests a bifurcation between man and matter, elsewhere he makes explicit that there is one law of nature that governs all. Indeed, acknowledging the mind's elemental properties seems a crucial first step up the ladder of mastery that he invites his readers to ascend.

Bacon's tendency to understand the acquisition of knowledge as an organic process has been demonstrated in Brian Vickers's valuable study of Baconian prose. As Vickers shows, images of natural growth, water, and light pervade Bacon's writing, as does a metaphorical predilection that leads him to compare knowledge to a tree, at once branching with growth while being firmly rooted in a conceptual trunk. ${ }^{21}$ Bacon presses these comparisons further in imagining the mind's natural topography. He describes it as having caverns and 'depths' that resemble the earth's subterranean regions-what he describes as the 'bowels of nature' (NO., 17)--as well as soil-like properties that require 
cultivation and ploughing in order to get rid of unwanted 'shoots of error' $(N O ., 19)$. But the images of water and fluidity that Bacon leans on to describe mental processes assume particular force in his writing, with the effect that the mind's activities are likened to the warring of elemental forces. Hence, cognitive groundedness is always threatened by liquid tides of thought and the specter of errancy, wandering, and shipwreck they evoke. ${ }^{22}$

Bacon had carefully examined these elemental dynamics as they gained expression in the terrestrial globe in his essay 'On the Ebb and Flow of the Sea. ${ }^{23}$ In this context, the earth's different topographical features-sea as against land-take shape as actors in a kind of cosmic drama. The tides of the sea-governed by what Bacon believes is a tendency to flow from east to west-are 'straitened, thwarted, and repelled by the opposition of land' ('Ebb and Flow,' 332), or 'disturbed by the furrows and inequalities of the bottom' ('Ebb and Flow, 320), or 'agitated by the winds' ('Ebb and Flow,' 320), even as they experience a kind of elemental conflict, since forceful currents 'overpower' the 'mild and gentle' motion of the tides, making them '[yield] to the pulse and direction of their violence' ('Ebb and Flow,' 321). Bacon's description of these natural events is framed in language that expresses the strong ties between the elemental sphere and the 'kingdom of man' (NO., 102). Indeed, even as he critiques classical philosophers such as the famed Pythagorean philosopher Apollonius of Tyana for viewing the world in anthropocentric terms ('Ebb and Flow,' 323)-for privileging man as the key that unlocks natureBacon, too, argues for deep correspondences between man, element, moon, and sea. In his view such connections 'arise out of the universal passions of matter, and the primary combinations of things, not as if one were governed by the other, but that both emanate from the same origins and fellow causes' ('Ebb and Flow,' 326-27). One upshot is that if there are passions in nature's elements - such that earth and sea can be 'agitated' and 'disturbed'—so there are tides that govern man's thought processes. ${ }^{24}$

Indeed the mind, as narrated by Bacon in his plan for the Great Instauration, has a natural tendency to be a lively, restless, and 'giddy' force (NO., 2). He repeatedly refers to its 'endless and aimless activity' (NO., 27), and its 'spontaneous movements' (NO., 28). In the churning, eddying, and circling motions that he associates with its activities, we hear a version of the circular flows of water that govern the tides. Like them, the waters of the mind tend to churn this way and that, exhibiting 'casual and undirected motions and cursory movements' (NO., 82) rather than any real progression. Indeed, in offering what he considers an inadequate yet typical definition of 'wet' as that which is 'without its own boundaries and unstable; and what easily gives way all round; and what easily divides and disperses . . . and what easily flows and is set in motion' (NO., 49), Bacon retraces the language and syntax he repeatedly uses for the mind. Just as a drop of water tends to '[leap] back up to avoid breaking' just before it drops to the ground (NO., 140), so the mind tends to 'leap and fly from particulars' to hasty, untested generalizations (NO., 83). This shared syntax expresses a kind of elemental affinity between mind and sea.
If liquidity is the brain's 'natural' state for Bacon, it need not constrain man, as it did classical writers. Their failure to sail beyond the Pillars of Hercules and to discover the New World he views as symptomatic of their flawed intellectual habits. He condemns them for styles of thought that are too passive in the face of the mind's currents. As he observes, 'before one can sail to the more remote and secret place of nature, it is absolutely essential to introduce a better and more perfect use and application of the mind and understanding (NO., 10-11). Classical philosophers failed to do so, allowing themselves and those who followed them to be caught in the 'eddy and whirl of argument,' by virtue of their tendency to ride on the 'waves and windings of chance and casual, unregulated experience' (NO., 67). The effect was that they had movement but not progress, leading them to be unable to finish 'the course' of scientific investigation, because 'they [had] wholly lost their way' by going 'round in circles' (NO., 68). In Bacon's estimation, Aristotle and his contemporaries were poor explorers, preferring to cling to the shores of unchallenged opinions, which 'stay and slugge the Shippe from furder sayling' ( $A d v$., 86), rather than to set sail on open seas: 'Just when the human mind, borne thither by some favouring gale, had found rest in a little truth, [Aristotle] presumed to cast the closest fetters on our understandings' and therefore 'turned [us] away from the perambulation of our globe. ${ }^{25}$ Fearing the rigor required of crossing intellectual and terrestrial seas, these philosophers clung to the shores of their flawed truths, thereby shipwrecking generations to come.

The solution, as conceived by Bacon, is not simply to invert the posture, raising our intellectual sails and hitting the high seas of unbounded thought. Rather, Bacon urges a precise form of mental restraint: 'from the very start the mind should not be left to itself, but be constantly controlled' (NO., 28). In the same way that ships require nautical aids such as the 'Mariners Needle' $(A d v$., 107) to guide their forward progress, so the mind needs material supports. Bacon speaks specifically of tools that will draw the mind's flows to a halt, cutting through its eddies and tides, just as a rudder cuts a path through the water. He notes that 'the human understanding is most affected by things which have the ability to strike and enter the mind all at once,' what he describes as things that take 'the mind by storm' (NO., 43). Likening the vessel of understanding to a ship, he argues that it is 'very slow and ill adapted to make the long journey to those remote and heterogeneous instances unless it is made to do so by harsh rules and the force of authority' (NO., 43). It exhibits 'lack of restraint,' 'indiscipline,' and '[ceaseless]' activity in its quest for 'something beyond' (NO., 44). Exhausting itself in the process of attempting to make sense of nature's complexity, Bacon observes how the mind, fatigued by the long journey of knowledge acquisition, ultimately retreats to 'final causes' and to the realm of the 'familiar' $(N O ., 44)$, thereby failing the enterprise of natural philosophy.

Determined to find a solution to this problem of cognitive backslide, Bacon echoes an idea first propounded by the classical writers whom he elsewhere sharply critiques when he proposes that wonder, what he describes as 'the seede 
of knowledge' or 'broken knowledge' $(A d v ., 8)$, could serve as a cognitive tool to help rectify this situation. As T.G. Bishop has demonstrated in his study of The Theatre of Wonder, such theories had classical provenance: 'For both Plato and Aristotle wonder occupied the ground between ordinary thought and philosophical inquiry.' Positioned between poetry and philosophy, wonder, for Aristotle, is 'intimately integrated with the business of "learning and reasoning out" that is the heart of mimesis,' while for Plato it is a 'switchpoint belonging at once to emotive and cognitive faculties.' A 'portal' to knowledge for both philosophers, wonder's powers lie in its ability to confound the human mind, offering it 'no secure resting-place' and thereby triggering further acts of 'questioning' as well as a 'habit of philosophizing. ${ }^{26}$ Indeed, as Bishop demonstrates, the etymological origins for wonder emphasized spectacle on the one hand, but the force of a violent blow on the other, making it a kind of 'rough magic' that assaults the viewer in delivering him the world. ${ }^{27}$ Compellingly, Bacon follows these classical philosophers in incorporating a theory of 'admirable works of art' (NO., 150) into the heart of his natural philosophy.

Observing that the human mind becomes inert in the presence of familiar phenomena that do not 'arrest and hold men's contemplation' (NO., 92), Bacon advocates techniques that serve to draw and sustain attention to such 'known things' ( NO., 92), so that nature may be intimately known. To this end he encourages natural philosophers to use art-specifically what he describes as 'harrassments applied by the arts' ( NO., 81) - to make the 'secrets of nature reveal themselves.' By practicing artful wonders-by which he means experiments that imitate Nature's marvels - the human understanding will move beyond the natural impasses that it encounters: 'As rare and unusual works of nature arouse and stimulate the intellect to seek and discover forms capacious enough to contain them, so too do outstanding and admirable works of art' (NO., 150). Artificially constructed wonders, like the natural wonders they emulate, act on the mind, drawing it out of its accustomed pattern of drift, through the shocking power of what it presents. Indeed he carves out an entire epistemological category in his history of nature for such works. His history embraces 'Nature in course; . . . Nature erring or varying; and . . Nature altered or wroght,' which he translates, respectively, as the 'history of creatures, the history of marvailes, and history of arts' ( $A d v ., 63)$. The goal of his philosophy is to allow the philosopher to progress from observing the 'Wonders of Nature' - which fall within his 'history of marvailes'-to successfully imitating such actions by means of man-made, artificial replications of such wonders, which he refers to as 'Wonders of Arte' (63). The path to such knowledge requires that scientists be active, not limiting themselves to following Nature's 'footesteppes' $(A d v$., 78) but rather intervening in her processes and making her go where she does not want to venture. Figuring Nature as an errant damsel, he calls upon scientists to '[hound]' her 'in her wandrings' ( $A d v$., 63), instructing them to wrench her away from familiar patterns and into marvelous ones so as to expose the laws that underpin all her activities. Such fabricated wonders will not only expose Nature's secrets but will take the human mind by storm, awakening it from its stupor on the path to new knowledge.

The view of the natural philosopher as a kind of artificer who co-creates with nature gains expression in the motif of the three insects- the ant, spider, and bee-that Bacon leans on to explain his ideal for science. While each of these insects engage in various relations with the material world, alternately collecting, spinning, and transforming the natural materials that they gather (Adv., 24; NO., 79), the reformed natural philosopher should model his work after the activities of the bee. Not limiting itself to collecting 'material from the flowers of the garden,' it takes the added step of '[converting]' such matter (NO., 79), transforming nectar into honey. By contrast, the ant merely collects raw material, while the spider spins webs of no intrinsic value, ensnaring itself in eddying patterns that Bacon associated with the intellectual habits of followers of Aristotle. Like the bee, the reformed natural philosopher must gather natural material and transform it in wondrous ways. Bacon thereby propounds a theory of natural philosophy that encourages his scientists to think of themselves as bee-like artisans engaging in mimetic acts of nature, performing transformative and creative work on the elemental world.

\section{Pericles's Cognitive Laboratory}

In the same years that Bacon was publicizing his reformed method of natural philosophy, Shakespeare and George Wilkins were actively collaborating on the highly experimental play, Pericles, a pastiche of classical and medieval dramatic forms such as Greek romance, the miracle play, the saint's life, and the chronicle, no less than the composite of tales and anecdotes that comprise the Gesta Romanorum. ${ }^{28}$ In his discussion of its many narrative sources, Bullough describes the play, and the 'romantic' mode he sees it as inaugurating, as a 'rambling' play that 'expressed a reaction against the comedy of Humours and the realism of Jonson and Middleton. ${ }^{29}$ Assembled from a diverse body of literary forms, rather than from the gritty reality of Jacobean London, the play for Bullough is an early expression of tragicomic romance, showcasing what many critics identify as its touchstone features of 'parted families, wanderings and searches, suffering and happy reunions'; in his view, the play is an experiment which Shakespeare 'was to apply more fruitfully in the last years of his career. ${ }^{30}$ In the introduction to his edition of the play, Roger Warren affirms this view of the play as marking a generic shift in Shakespeare's writing, describing it, in a nod to Philip Edwards, as the door through which 'Shakespeare "undoubtedly enters the world" of his late plays. ${ }^{.31}$ Indeed, like the late plays, conventionally clustered together under the rubric romances, Pericles seems to announce its distance from a mimetic, naturalistic style of representation, insofar as it brings the medieval moralistic poet, John Gower, onstage to narrate its events and abides by a highly disjointed, episodic, and emblematic style of representation. At every turn the play seems to showcase its artifice, revealing its narrative seams in ways that block engagement with the play as a window 
onto the empirical world. Such representational choices led Howard Felperin to speculate that Shakespearean romance would not have pleased an empiricist like Bacon, whom Felperin argues might have had reason to regard Jonson's realist drama, with its emphasis on the exposure of human wickedness, as more palatable. ${ }^{32}$ As Felperin observes, 'In Pericles the impulse to hold the mirror up to nature all but gives way to the impulse to create a moral vision.' Bacon, one might surmise, would dismiss the play as mere 'wish fulfillment,' a dream of the world rather than its mimetic reproduction. ${ }^{33}$

But the tendency to see the play as fundamentally at odds with Baconian science, I will argue, is to allow a limited definition of mimesis-one based on content rather than form-to gauge its value to contemporary epistemological debates. For like Bacon's new philosophy, the play privileges a form of representation that values artfully rendered wonders patterned after natural marvels. As a play that foregrounds the central motif of the tempest, human perambulations in the Mediterranean seaboard, and attempts to make sense of wondrous natural disasters, it intersects at a deep conceptual level with the tropes that shape Bacon's account of the cognitive process. Like Bacon's view of the cognitive challenges facing natural philosophers, the play construes the human mind as a sea-like organ buffeted by storms of passion. And like Bacon, who advocates that his scientists practice artisanal work to overcome the mind's limits, the play explores how the process of mingling human labor with nature-a craft-based conception of art-can cut a path through the mind's seas and reconfigure cognitive drift into a species of knowledge.

Indeed, critics have long understood the sea in Pericles as a character in its own right, turbulently advancing the fortunes of its title character no less than his family. But increasingly critics have come to view the mutable sea less as an agent external to the characters than as an emblem of their internal, cognitive life. ${ }^{34}$ As Roychoudhury demonstrates, equating the mind with the sea was commonplace for the period-visible in emblems and proverbs, no less than in the drama- and Shakespeare makes frequent use of it across his corpus. The motif appears at the concluding moment in The Tempest when Prospero, ready to release his enemies from the tortures he has imposed on them, observes: 'Their understanding/Begins to swell, and the approaching tide/Will shortly fill the reasonable shore/That now lies foul and muddy' (5.1.79-82). He compares the faculty of understanding to a purging body of water that clears the mind's shores of an encasing muck as it moves toward apprehension. So, too, when Iago cautions Othello that his suspicions of Desdemona may falter and that his 'mind may change' (3.3.447), Othello counters by deploying the motif of the mind as a sea in order to emphasize the fixity of its course: 'Never, Iago! Like to the Pontic Sea,/Whose icy current and compulsive course/Ne'er keeps retiring ebb, but keeps due on/To the Propontic and the Hellespont,/Even so my bloody thoughts, with violent pace,/Shall ne'er look back, ne'er ebb to humble love' $(3.3 .448-52)$. Like the virtually landlocked Pontic, thought to be immune to tidal flux, Othello describes the course of his vengeance as surging forward without cease.
Similarly, Pericles describes the experience of his cognitive life as akin to staying afloat amid rising waters, when, discovering Marina's true identity, he tells Helicanus to halt the surge overtaking him: 'strike me, honoured sir, / Give me a gash, put me to present pain, / Lest this great sea of joys rushing upon me / O'erbear the shores of my mortality' (21.179-82). If here his life is equated with the stability of land, besieged by the invading waters of joyful passion, the play elsewhere imagines no such tidy divisions within the psyche, imagining the human project of living as entailing constant negotiation of internal waters. Indeed, Pericles's journeys by sea, wherein he is tossed 'By waves from coas to coast' (5.34), correspond to passionate surges within him-whether it be the 'fire of love' (1.96) that drives him to Antiochus, the fear of death which propels him to Tarsus, or 'pining sorrow' (2.38) for his daughter that finds him drifting toward Mytilene. In each case, his journeys by sea serve as a representation of his turbulent cogitations, what Hopkins describes in a terra-centric lexicon as the play's 'Greece of the mind. ${ }^{35}$ In fact, this experience of being buffeted about by external forces- the 'sea of troubles' (3.1.61) that Hamlet elsewhere evokes in soliloquy - engulfs the audience too, since the formal features of the play-its rapid shifts of scene and the rupturing effects of Gower's dissonant, antiquated verse-produce a sea-like theatrical experience, as we are jostled from one event to the next. When Pericles arrives to Tarsus in the hopes of retrieving his daughter, Gower instructs us to 'think his pilot thought; So with his steerage shall your thoughts go on' (18.18-19), later urging that we follow his movements and 'turn our thoughts again' (20.12). The cognitive experience of viewing the play thereby imitates Pericles' mental life: our thoughts 'turn' and 'go on' in turbulent fits and stops.

In defining the titular king by these passionate flows-not least by the 'dulleyed melancholy' (2.2) that grips him upon his return from Antioch - the play breaks with patterns visible in its sources. Compellingly, Gower's Confessi Amantis and Twine's Patterne of Painefull Adventures ${ }^{36}$ distance the Pericles figure - who bears the name Apollonius, possibly after the famous Pythagorean philosopher Apollonius of Tyana-from cognitive turmoil, emphasizing the scholarly and intellectual aspects of the protagonist. ${ }^{37}$ Each of these source assigns the tumultuous experience of passion to the people of Tyre, as if to dem onstrate their natural subjection. Gower notes how his people suffer a 'maladie' (1. 488) when their ruler abruptly departs for foreign lands, while Twin describes the people as 'drowned in heaviness' (43) at his loss. Meanwhile Apollonius is positioned above the fray, defined by Gower as a scholar of 'naturall science' (1. 398) and by Twine as a man of learning who consults 'all hi: books' (429) before fleeing to preserve his life. Apollonius emerges in thesc sources as the composed sage or magus, a traditional ideal that Bacon wa eager to replace with an everyman who arrives at illumination through slov and steady labor rather than natural wisdom. ${ }^{38}$

In Shakespeare and Wilkins's play, by contrast, such postures of epistemo logical mastery are the fleeting signs of Pericles's youthful disposition, wher he embodies a suspect confidence toward the material world that resemble: 
philosophers of old. We see such a world-making man in the opening scenes of the play, as Pericles leaves for Antioch, overly confident in his powers to win Antiochus's daughter where hundreds before him have failed. His posture is heroic, chivalric, and inflated, shaped by a simplified view of the world that aligns with Gower's pat moralism as expressed in his early appearances as chorus. ${ }^{39}$ Pericles's hubris in believing himself worthy of winning the princess translates as an attitude toward nature at large, since the princess emerges in his eyes as an emblem of Flora, a 'fair Hesperides' (1.70) 'apparelled like the spring' (1.55), who inflames his desire to 'taste the fruit of yon celestial tree' (1.64). Indeed, his will to claim her implies a denial of his earthliness, a drive that hovers beneath his maxims to recall that 'life's but breath' and 'Grip not at earthly joys' $(1.89,92)$. If he thinks the task of tasting and knowing-concepts etymológically connected through the Latin word sapere-can be easily encompassed, the episode reveals his error. Her father's law, a kind of divine mandate, has made her an untouchable deity, 'Fit for th'embracements even of Jove himself' (1.49-50), even as it seeks to trap her wooers in a paralyzing, specular 'awe' (1.36). Pericles describes to Helicanus the transfixing effects of her beauty - 'Her face was to mine eye beyond all wonder' (2.80)and her father's power, 'so huge / Amazement shall drive courage from the state' (2.25-6). Both transmit the paralyzing aura of natural wonders. Pericles quickly learns that knowing (her) has hazards, precipitating his descent into a malady that '[wastes]' his body (2.38) and suppresses his desire to 'know the world' (1.91).

Like Bacon's philosopher of old, the challenge of knowing sets him adrift on literal and cognitive seas. Besieged by the play's first storm, in which he loses all his worldly possessions, Pericles espouses the stoical posture that will define him for much of the play: 'earthly man/Is but a substance that must yield to you, / And I, as fits my nature, do obey you' (5.4l-3). His tendency here is to view man as a creature subject to nature-'A man whom both the waters and the wind / In that vast tennis-court hath made the ball' (5.99-100). He experiences himself as abjected by Nature's awful power, accepting the loss, first, of his princely identity — describing himself at Pentapolis as only a 'gentleman of Tyre' (7.77) — and then of his human identity in forsaking the qualities that hold him apart from the beast - speech and comportment. Pericles feels himself reduced to bare life when he observes that the storm 'left my breath / Nothing to think on but ensuing death' (5.46-7). The animating power of thought - the life-breath or anima - has died in him. Here, as elsewhere in the play, the awesome power of Nature appears to be at odds with man, its wondrous powers-storms, earthquakes, lightning-overpowering him, rendering him passive and powerless.

And yet, as the play advances, it opens up another possibility altogether in directing our attention to characters who do not presume that their nature is alien to Nature, as Pericles does. They seek instead to forge composites of their own productions with those of Nature. Such actions are granted the power to arrest the cognitive drift that Pericles experiences when he assumes he can neither speak openly to Antiochus nor sail the stormy seas. These characters, by contrast, view 'the disturbances that nature works' $(12.33-4)$ as portals that invite their participation, rather than barriers that abject them. We see a comic version of this technique embodied by the fishermen as they witness Pericles's ship sinking. This account echoes a famous moment in Lucretius's De Rerum Natura, in which a philosopher observes from a vantage point on land the tribulations of men experiencing a shipwreck. ${ }^{40}$ For the play's fishermen, watching Pericles's shipwreck evokes what Steve Mentz describes as 'the power of the philosophical mind, resting firm on the bedrock of reason, to make sense of the world's disorder. ${ }^{41}$ These everyday philosophers reflect on the correspondences between sea and land, nature and society, comparing 'rich misers' to a 'whale' that 'plays and tumbles ... and at last devours' men, since they, too, prey upon 'whole [parishes].' Compellingly, the third fisherman, imagining himself trapped along with the church in the belly of a whale, describes how he would defy death by keeping 'such a jangling of the bells that he should never have left till he cast bells, steeple, church, and parish up again' (5. 81-83). By producing a jarring noise, the man imagines how he might pressure the whale, redirecting its appetite and rescuing himself. A similar dynamic is staged when the fishermen retrieve armour from the 'rough seas' (5.125). When Pericles begs them to allow him to use the armour, which sank with his ship, to compete in the tournament, the second fisherman responds: 'Ay, but hark you, my friend, 'twas we that made up this garment through the rough seams of the waters' (5.186-8). In his words 'rough seas' morph into 'rough seams,' with the watery empire refigured as a fabric to be spun into something new-here a garment that will 'repair' the losses (5.161) of the beleaguered Pericles. But the garment, like the jangling bells, points to an idea underpinning the entire play: that claiming full humanity requires co-producing with nature.

Cerimon translates this idea from the marine to the medical world, where the power of co-producing with Nature spells the difference between life and death. He, like the fishermen, is attentive to but not passive before Nature, a priest-like minister of her powers in applying his 'secret art' (12.29). His work has 'made familiar ... the blest infusions / That dwells in vegetives, in metals, stones' (12.32-33), revealing Nature's 'disturbances' but also her 'cures' (12.34-35). He uses this knowledge to extend Nature's powers, yielding an artificial wonder when he applies 'rough ... music' (12.86) and other sensory stimuli to the seemingly dead Thaisa. Notably, the music he uses to awaken her is broken, coarse, and jarring, agitating the human material that it works upon. Not only does the rough art he applies restore 'life's flower' (12.93) to the queen when 'Nature awakes' (12.90) in her, but it has a similar effect on the spectators, who acknowledge the moment's transformative effect on them: 'The heavens / Through you increase our wonder' (12.94-95). Notably, in the sources for the play, it is the queen's natural beauty that expresses a wonder. In the Anglo-Saxon version of the Apollonius story, the wife's beauty strikes 'all the spectators with astonishment,' since she is a 'perfect model, flashing through with the divine spark of soul her Creator had implanted.' 
She emblematizes nature's powers, since her hair is like snow, her eyes like two orbs, her neck white as solar rays, and her arms like branches of trees. ${ }^{42}$ The play, by contrast, locates wonder at the juncture of nature and human art, at the points of contact between the queen's physical body and Cerimon's application of medicine, music, and speech. His act of healing makes him a Baconian natural philosopher, one who produces an 'admirable [work] of art' (NO., 150) through close scrutiny of nature's powers.

But it is Marina who brings the idea of the knowledge-maker-of poetic science - to the realm of visual and language arts. Cerimon's craft, if creative, nevertheless belongs to the realm of medicine, a field whose ties to science and knowledge-production modernity already grants. But Marina's knowledgecraft - an analog for Cerimon's medicine and the fisherman's bells-is lodged squarely within the creative arts, associated with needlework and, most especially, storytelling. She, therefore, is the crux that bridges science and art most fully in this play. Her life story figures a radical union of natural and human terms. Born at sea, she is described as a 'piece of nature,' a vigorous blend of elements: 'Thou had as chiding a nativity / As fire, air, water, earth, and heaven can make' (11.31-34). She is Nature's production, the 'heart and place / Of general wonder' (15.10-11) whose beauty rivals that of Antiochus's daughter. But where the play's first princess was a lifeless idol-generating death in her incestuous clasp-Marina is figured as an artisan, engaging in 'chiding' or 'rough' acts of creation like Nature. She embodies the active disassembling and re-creation of nature: her needlework makes 'The cambric ... more sound / By hurting it' (15.24-5), and her song makes the 'night bird mute / . . with moan' (15.26-7). Her works vie with nature, transforming its forms through acts of reassembly that are described as violent and active, evoking pain and moans from the fabric of nature she reworks. Indeed, her art might be said to 'harass' nature in ways that resemble Bacon's instructions for natural philosophers. And yet her creative acts are also those of a poet, since she '[weaves]' - a word derived from the Latin texteve - sleided silk' (15.21) and 'with rich and constant pen/[Vails] to her mistress Dian' (15.18-19). If she serves as the play's lively emblem of human art, her captors yet seek to halt her 'artificial [feats]' (21.62), to reduce her to an idol that will transfix her (paying) spectators. Hence Bolt - whose name fittingly echoes the natural wonder he seeks to make her-plans to parade her through the marketplace to unleash a spell over men: 'I warrant you, mistress, thunder shall not so awake the beds of eels as my giving out her beauty' (16.134). If he speaks of awakening men to her sexual appeal, the scenario he imagines actually replays the parade of 'speechless tongues' (1.79) in Antioch, promising to ensnare suitors in a passive trance and to transform Marina into the living dead. As the Bawd tells her, 'you're a young foolish sapling, and must be bowed' (16.80), replicating the emblem of a withered branch that her father takes as his insignia in the tournament at Pentapolis.

But Marina eludes their plans through her artistic use of language. She brings order to the surges that batter her by means of speech-acts that recollect her history and provide a kind of mental navigation. In an exchange with Leonine moments before she is seized by pirates, she recounts the story of her birth, recalling how 'Never was waves nor wind more violent' (15.110). But her speech-act also recollects human art or techne in response to Nature's assaults, emphasizing her father's skill in managing the storm, the fact that he '[Galled] his kingly hand with haling ropes' to '[endure]' the sea (15.105-06). If such recollections are useful to her, they also elicit acts of co-creation from her interlocutors, performing a kind of rough magic that awakens them spiritually. Lysimachus describes her words as effecting 'alarm' and 'battery' (21.36-37), while the Bawd speaks of 'her quirks, her reasons, her master reasons, her prayers' (19.16-17). Powerful, sharp, and evasive, her words serve as a tool that sets to work on the men of the brothel, converting them into penitents through their violent, piercing force. Her words assail them, snapping them out of passionate drift and activating their rational faculty. But we witness their most spectacular effects on Pericles when she halts his deathlike trance by awakening his will to know the world.

Her riddling method practices a technique that resembles Baconian aphorism, sending verbal jolts to the catatonic Pericles, in a slow and steady process of cutting through the stupor that has come to own him. Her words jar, disrupt, and annoy like the 'chiding' (11.32) work of Nature at her 'nativity' (11.32), and like the 'rough music' (12.86) that Cerimon applied to Thaisa. The life story she tells Pericles-reluctantly, hesitatingly, disjointedly-seems designed to draw him into the productive work of the story. His questions are met with partial answers and terse responses, denying him closure and the comfort of a full picture, and requiring that he engage the creative act by posing further questions. Her words cut through his cognitive turmoil, flashing into his mind like the comet to which she compares herself (21.76), enlightening and enlivening him in the process. Like the artificial wonders that Bacon values, her words elicit the desire for more information: 'didst thou not say' (21.116); 'tell thy story' (21.124); 'how thou dost startle me' (21.137). It is this story of her life - a hybrid union of Nature's wonders and human art-that halts Pericles' fall into oblivion. A co-creator with nature, Marina's art embodies the goal of Baconian science: to awaken the drive to know.

Pericles responds in kind, discovering his long-lost daughter and attaining a more intimate knowledge of the cosmos when he hears the music of the spheres. But the awakening does not end there. The play offers one more emblem of divine power, when Diana descends from on high and speaks to him in his dream. It is not enough for him to listen, not enough that he subject himself to her power. Instead she puts him to work, urging him to travel to Ephesus and pronounce in 'full voice' (21.230) his history; 'give them repetition to the life' (21.233), she commands. In the final scene of the play, this act of recollection-which is nothing less than an 'admirable work of art' in conjoining his art with the raw material of his life-radiates outward into the community. It awakens Thaisa a second time, and then —at the hands of Gower, 
Wilkins, and Shakespeare-acts on its audience, who become the instrument to be played upon by the 'magician's bow' of the theater (De Aug., 8:441).

If, as Warren and other have argued, Shakespeare's 'romances' are the least mimetic of the various dramatic forms in his corpus, in straying far from the empirical world with their highly stylized representations, it is also evident that they bear deep continuities with the epistemological projects of their moment and the more capacious ways that early moderns imagined knowledge-making to occur. The new science embraced by Bacon worried the limits of the human mind and identified artificial wonders as a support for it, viewing art as a tool that could navigate humankind to a wide new world of knowledge. At the same time, early modern dramatists were inventing their own cognitive laboratory in the form of a new dramatic hybrid that placed a premium on nature, artifice, and the wondrous. This mode insisted on a view of Nature as a creative force, a principle that such plays also located at the core of human identity. By working on nature, disassembling and reassembling her raw material through studied forms of art, humankind might move beyond a state of passivity, pummeled about by the storms and tides of life, to a position of greater epistemological stability. Like the rudder, sail, or medicine, art was viewed as an artisanal tool that allowed the practitioner to co-produce with nature, as a means of obtaining a deeper, more sound knowledge of the world. Together these thinkers remind us of another way of organizing intellectual labor, recollecting how science was once artful and poesis once bound to knowledge of the material world.

\section{Notes}

1. See C.P. Snow, The Two Cultures and the Scientific Revolution (Cambridge: Cambridge University Press, 1988); see also the detailed discussion of Snow's work in Howard Marchitello, The Machine in the Text: Science and Literature in the Age of Shakespeare and Galileo (Oxford: Oxford University Press, 2011), ch. 7. Marchitello demonstrates that Snow's 'two cultures,' though often taken to refer to the fields of science and literature, may have been a reference to the division of society into discrete classes of rich and poor.

2. Bacon, The Advancement of Learning, ed. Michael Kiernan, The Oxford Francis Bacon, vol. 4 (Oxford: Oxford University Press, 2000), 73. All subsequent references to this text will refer to this edition and will be cited parenthetically in the text as $A d v$. with reference to page number.

3. Compellingly, Howard Felperin suggests that the 'mimetic empiricism" evident in Ben Jonson's satiric comedies is the kind of drama of which Bacon would approve, since it keeps its 'eye steadily fixed upon the facts of nature' ( $A d v$., Preface), as compared with the non-mimetic 'comedy of amendment' of Shakespeare's romances; see Shakespearean Romance (Princeton, NJ: Princeton University Press, 1972), 107-09. I suggest that what links Shakespeare to Bacon is not overlap as regards the content of representations so much as the model of cognition they both work with and the role afforded wonder as a tool of knowledge. On this front Shakespeare's 'romances' do indeed speak to Bacon's theories.

4. For a discussion of Bacon's understanding of the three branches of knowledge-poesy, history, and philosophy - see Sachiko Kusukawa, 'Bacon's Classification of Knowledge' in The Cambridge Companion to Bacon, ed. Markku Peltonen (Cambridge: Cambridge University Press, 1996), 47-74, especially 52-54. See also Brian Vickers, 'Bacon and Rhetoric' in the same volume, 200-31

5. Bacon, The Dignity and Advancement of Learning (translation of the De Augmentis) in The Works of Francis Bacon, eds James Spedding, Robert L. Ellis, and Douglas D. Heath, 14 vols. (London: Longman, 1857-74), 8:440. All future citations of De Augmentis Scientarium will refer to this volume and will appear parenthetically as De Aug. with reference to page number.

6. Kusakawa, 'Bacon's Classification,' 54

7. The phrase 'poetic science' is the full translation of the Greek word that Aristotle used as the title for the Poetics. In his translation of the treatise, Kenneth A. Telford observes that an appropriate translation for the Greek title would be 'Concerning the Productive or, by implication, Concerning Productive Science' (1, n. 1). He further argues that 'Poetic or productive science for Aristotle covers any kind of making, including the products of both useful and fine art, but only in respect of their production, not in respect of any external criterion or purpose they might serve' (1, n. 2); see Aristotle's Poetics: Translation and Analysis (Chicago: Henry Regnery, 1961).

8. In her article 'Mental Tempests, Seas of Trouble: the Perturbation of Shakespeare's Pericles' (English Literary History 82, no. 4 (2015): 1013-39), Suparna Roychoudury provides an overview of the proverbial equation of mental activity with the sea in early modern texts.

9. Indeed the same promise is made to the king in the section of the Gesta Grayorum contributed by Bacon as part of the Gray's Inn Revels, 1595-96. This occurs when the sixth counselor, who appears to be 'Bacon's spokesperson' (Marchitello, Machine, 38), recommends the study of philosophy to the king. He notes, 'when your Excellency shall have added depth of Knowledge ... then when all other Miracles and Wonders shall cease, by reason that you shall have discovered their natural Causes, your self shall be left the only Miracle and Wonder of the World'; see Gesta Grayorum: Or, The History of the High and Mighty Prince Henry Prince of Purpoole, Anno Domini 1594, ed. D. Bland (Liverpool: Liverpool University Press, 1968). See also Marchitello's analysis of this event, Machine, 24-50.

10. See the excellent discussion of Aristotle's theory of wonder in T.G. Bishop, Shakespeare and the Theatre of Wonder (Cambridge: Cambridge University Press, 1996), 17-41. 
11. Bacon, The New Organon, eds L. Jardine and M. Silverthorne (Cambridge: Cambridge University Press, 2000), 150. All references to this text are to this edition and will be cited parenthetically in the text with reference to page number.

12. See Ronald S. Crane, 'The Relation of Bacon's Essays to His Program for the Advancement of Learning' in Essential Articles for the Study of Francis Bacon, ed. B. Vickers (Hamden, CT: Archon Books, 1968), 272-92, especially 284. For aphorism as illumination, see Vickers, Francis Bacon and Renaissance Prose (Cambridge: Cambridge University Press, 1968), 91.

12. Francis Bacon, The New Organon, ed. Lisa Jardine and Michael Silverthorne (Cambridge University Press, 2000), 92 and 150-1. All subsequent references to this text will refer to this edition and will be cited parenthetically in the text as NO.

13. For connections between poesis and the artisan's craft, see Elizabeth Spiller, Science, Reading, and Renaissance Literature: The Art of Making Knowledge, 1580-1670 (Cambridge: Cambridge University Press, 2004).

14. Bacon, The Masculine Birth of Time or Three Books on the Interpretation of Nature in The Philosophy of Francis Bacon: An Essay on its Development From 1603-1609, ed. Benjamin Farrington (Liverpool: Liverpool University Press, 1964), 85.

15. Peltonen, Introduction to The Cambridge Companion to Bacon, 17.

16. This is the premise of the important study by Antonio Pérez-Ramos, Francis Bacon's Idea of Science and the Maker's Knowledge Tradition (Oxford: Oxford University Press, 1989). Paolo Rossi echoes his thesis in noting that 'an intimate relationship between objects of cognition and objects of construction' informs Bacon's natural philosophy; see 'Bacon's Idea of Science' in Cambridge Companion to Bacon, ed. Peltonen, 25-46, especially 38 .

17. For this phrase, see Laurie Shannon, 'Poor, Bare, Forked: Animal Sovereignty, Human Negative Exceptionalism and the Natural History of King Lear,' Shakespeare Quarterly 60, no. 2 (2009): 168-96.

18. The reference to 'flexuous' is from The Advancement of Learning, as quoted by Vickers, Francis Bacon and Renaissance Prose (Cambridge: Cambridge University Press, 1968), 180. I draw the synonyms for flexuous from the OED; see flexuous, adj., 1 and 2 .

19. For discussion of theories of the mind in a pre-Cartesian moment, see Jonathan Sutton, Philosophy and Memory Traces: Descartes to Connectionism (Cambridge: Cambridge University Press, 1996).

20. See Vickers, Renaissance Prose, 194-6.

21 . For the prevalence of motifs of storm, tempest, and shipwreck in Bacon's writings, see Vickers, Renaissance Prose, 185-8.

22. Bacon, 'On the Ebb and Flow of the Sea,' in The Works of Francis Bacon, eds Spedding, Ellis and Heath, 10:317-40.
23. Gail Kern Paster, Katherine Rowe, and Mary Floyd-Wilson make this point in their Introduction to Reading the Early Modern Passions (Philadelphia: University of Pennsylvania Press, 2004): 'human emotional expressions are analogous to the weather,' just as 'the weather is correspondent with human emotions' (17-18).

24. Bacon, The Masculine Birth of Time in The Philosophy of Francis Bacon: An Essay on its Development From 1603-1609, ed. Farrington, 63

25. For these quotations, see Bishop, Theatre of Wonder, 4, 19, and 21

26. Bishop, Theatre of Wonder, 8. He borrows the phrase 'rough magic' from Prospero, who uses it as a synonym for the 'potent art' he promises to abjure; see The Tempest, Norton Shakespeare, eds Stephen Greenblatt, Walter Cohen, Jean E. Howard, and Katharine Eisaman Maus (New York and London, 1997), 5.1.50; all subsequent quotations of Shakespeare plays other than Pericles are to the Norton edition. Indeed, Prospero's 'rough' art might be understood to embody precisely the kind of natural philosophy that Bacon advocates insofar as his magic cognitively jolts his victims out of their complacency and into forms of self-knowledge. As Alonso observes in being released from its grip: 'Th' affliction of my mind amends' (5.1.117). Compellingly, both Shakespeare and Bacon emphasize the value of art that is 'rough' or violent, since only this kind of art can pierce the cognitive stupor that defines the human mind.

27. For a full discussion of sources, see Geoffrey Bullough, ed., Narrative and Dramatic Sources of Shakespeare, 8 vols. (London: Routledge and Kegan Paul; New York: Columbia University Press, 1966), 6:349-72.

28. Bullough, ed., Narrative and Dramatic, 6:369.

29. Bullough, ed., Narrative and Dramatic, 6:373-4. For a critique of the generic tag 'romance' to describe Shakespeare's late plays, and for the late provenance of this category, see Cyrus Mulready, Romance on the Early Modern Stage: English Expansion Before and After Shakespeare (Houndmills, Basingstoke: Palgrave, 2013), ch. 1.

30. Roger Warren, ed., Introduction to A Reconstructed Text of Pericles, Prince of Tyre (Oxford: Oxford University Press, 2003), 8. All subsequent quotations of Pericles refer to this edition and will be cited parenthetically with reference to scene and line numbers.

31. See Felperin, Shakespearean Romance, 106-9. Evidence suggests that Jonson was no fan of Shakespearean romance, since his 'Ode to Himself' ridicules Pericles as a 'moldy tale' that heaps 'Scraps out of every dish ... into the common tub'; see Ben Jonson: The Complete Poems, ed. G. Parfitt (New York: Penguin, 1988), 282-83.

32. Felperin, Shakespearean Romance, 158 and 106.

33. For a sampling of such views, see Roychoudury, 'Mental Tempests'; Lisa Hopkins, "The Shores of My Mortality": Pericles' Greece of the Mind' in Pericles: Critical Essays, ed. David Skeele (New York and 
London: Garland, 2002), 228-37; Lorena Laureano Dominguez, 'Pericles" "Unknown Travels": the Dimensions of Geography in Shakespeare's Pericles,' Sederi 19 (2009): 71-97.

34. Hopkins, "The Shores of My Mortality."

35. For Confessio Amantis, see Narrative and Dramatic Sources, ed Bullough, 6:375-42, especially 398-41; for The Patterne of Painefull Adventures, see Narrative and Dramatic Sources, ed. Bullough, 6:423-82, especially 429.

36. See Elizabeth Archibald, Apollonius of Tyre: Medievaland Renaissance Themes and Variations (Cambridge: D.S. Brewer, 1991). She notes that the philosopher Apollonius of Tyana, like Apollonius of Tyre and Pericles, 'travelled widely, visiting Antioch, Tarsus and Ephesus' (42). She further notes that he took a vow of silence, grew his hair long, was responsible for relieving a famine, and was associated with riddles.

37. See Rossi in Cambridge Companion, ed. Peltonen, 32-33.

38. See Felperin's Shakespearean Romance for Gower as an embodiment of the 'medieval Poeta,' who 'speaks and behaves like the protagonist of a morality play' (149).

39. Lucretius, On the Nature of Things, Trans. Frank O. Copley (New York: Norton, 1977), Bk 2, 11. 1-19.

40. Steve Mentz, At the Bottom of Shakespeare's Ocean (New York: Continuum, 2009), 21. See also his discussion of this moment in the play at 72-74.

41. See Apollonius, The Anglo-Saxon Apollonius of Tyre, Trans. B. Thorpe (United States: Nabu Press, 2014), 54-55.

\section{BiBLIOGRAPHY}

Apollonius of Tyre, Upon which is Founded the Play of_Pericles, attributed to Shakespeare; From a ms. in the Library of C.C.C. Cambridge, with a Literal Translation by Benjamin Thorpe, F.S.A. 1834. London.

Archibald, Elizabeth. 1991. Apollonius of Tyre: Medieval and Renaissance themes and variations. Cambridge: D.S. Brewer.

Bacon, Francis. 1857-74a. The dignity and advancement of learning. In The works of Francis Bacon, eds. James Spedding, Robert L. Ellis, and Douglas D. Heath, vols. 8 and 9,14 vols. London: Longman.

and 9, 14 vols. London. In wo works of Francis Bacon, eds. James Spedding, Robert L. Ellis, and Douglas D. Heath, vol. 10, 14 vols. London: Longman.

1964. The masculine birth of time or three books on the interpretation of nature. In The philosophy of Francis Bacon: An essay on its development from 1603-1609, ed. Benjamin Farrington. Liverpool: Liverpool University Press.

1968. In Gesta Grayorum: Or, the history of the high and mighty Prince Henry Prince of Purpoole, Anno Domini 1594, ed. D. Bland. Liverpool: Liverpool University Press. 2000a. The advancement of learning. In The Oxford Francis Bacon, vol 4, ed Michael Kiernan. Oxford: Oxford University Press.

. 2000b. In The new organon, ed. L. Jardine, and M. Silverthorne. Cambridge: Cambridge University Press.

Bishop, T.G. 1996. Shakespeare and the theatre of wonder. Cambridge: Cambridge University Press.

Bullough, Geoffrey, ed. 1966. Narrative and dramatic sources of Shakespeare, 8 vols. London/New York: Routledge and Kegan Paul/Columbia University Press.

Crane, Ronald S. 1968. The relation of Bacon's Essays to his program for the advancement of learning. In Essential articles for the study of Francis Bacon, ed. B. Vickers, 272-292. Hamden: Archon Books.

Dominguez, Lorena Laureano. 2009. 'Pericles' "Unknown travels": The dimensions of geography in Shakespeare's Pericles. Sederi 19: 71-97.

Felperin, Howard. 1972. Shakespearean romance. Princeton: Princeton University Press. Hopkins, Lisa. 2002. "The shores of my mortality": Pericles' Greece of the mind. In Pericles: Critical essays, ed. David Skeele, 228-237. New York/London: Garland.

Jonson, Ben. 1988. Ode to himself. In Ben Jonson: The complete poems, ed. G. Parfitt, 282-283. New York: Penguin.

Kern Paster, Gail, Katherine Rowe, and Mary Floyd-Wilson. Reading the early modern passions. Philadelphia: University of Pennsylvania Press, 2004.

Kusukawa, Sachiko. 1996. Bacon's classification of knowledge. In The Cambridge compan ion to Bacon, ed. Markku Peltonen, 47-74. Cambridge: Cambridge University Press.

Lucretius. 1977. On the nature of things. Trans. Frank O. Copley. New York: Norton.

Marchitello, Howard. 2011. The machine in the text: Science and literature in the age of Shakespeare and Galileo. Oxford: Oxford University Press.

Mentz, Steve. 2009. At the bottom of Shakespeare's ocean. New York: Continuum.

Mulready, Cyrus. 2013. Romance on the early modern stage: English expansion before and after Shakespeare. Basingstoke: Palgrave.

Peltonen, Markku. 1996. Introduction. In The Cambridge companion to Bacon, ed. Markku Peltonen, 1-24. Cambridge: Cambridge University Press.

Pérez-Ramos, Antonio. 1989. Francis Bacon's idea of science and the maker's knowledge tradition. Oxford: Oxford University Press.

Rossi, Paolo. 1996. Bacon's idea of science. In The Cambridge companion to Bacon, ed. Markku Peltonen, 25-46. Cambridge: Cambridge University Press.

Roychoudury, Suparna. 2015. Mental tempests, seas of trouble: The perturbation of Shakespeare's Pericles. English Literary History 82(4): 1013-1039.

Shakespeare, William. 1997. The Tempest. In Norton Shakespeare, ed. Stephen Greenblatt, Walter Cohen, Jean E. Howard, and Katharine Eisaman Maus. New York/London W.W. Norton.

Shannon, Laurie. 2009. Poor, bare, forked: Animal sovereignty, human negative exceptionalism and the natural history of King Lear. Shakespeare Quarterly 60(2): 168-196.

Snow, C.P. 1988. The two cultures and the scientific revolution. Cambridge: Cambridge University Press.

Spiller, Elizabeth. 2004. Science, reading, and Renaissance literature: The art of making knowledge, 1580-1670. Cambridge: Cambridge University Press.

Sutton, Jonathan. 1996. Philosophy and memory traces: Descartes to connectionism. Cambridge: Cambridge University Press. 
444 J.E. FEERICK

Telford, Kenneth A. 1961. Aristotle's Poetics: Translation and analysis. Chicago: Henry Regnery.

Vickers, Brian. 1968. Francis Bacon and Renaissance prose. Cambridge: Cambridge University Press.

-. 1996. Bacon and rhetoric. In The Cambridge companion to Bacon, ed. Markku Peltonen, 200-231. Cambridge: Cambridge University Press.

Warren, Roger. 2003. Introduction. In A reconstructed text of 'Pericles, Prince of Tyre', ed. Roger Warren, 1-80. Oxford: Oxford University Press. 